\title{
KAJIAN PSIKOLOGIS BERPIKIR DALAM AL-QUR'AN DAN HADITS
}

\author{
Alfiana Chofifah
}

Psikologi Pendidikan Islam, Pascasarjana UIN Sunan Kalijaga Yogyakarta

Alfianachofifah47@gmail.com

\begin{abstract}
Abstrak, Berpikir adalah proses menyajikan atau memanipulasi pengalamanpengalaman secara lebih lengkap, misalnya dalam melakukan proses memanggil kembali informasi, membayangkan dan mempertimbangkan sesuatu. Berpikir berarti memproses informasi secara mental atau secara kognitif. beberapa pandangan dasar dalam berpikir Berpikir adalah kognitif, yaitu timbul secara internal dalam pikiran tetapi dapat diperkirakan dari perilaku, Berpikir merupakan sebuah proses yang melibatkan beberapa manipulasi pengetahuan dalam sistem kognitif, dan Berpikir diarahkan dan menghasilkan perilaku yang memecahkan masalah. Menurut Piaget, cara berpikir logis berkembang secara bertahap, kira-kira pada usia dua tahun dan pada sekitar tujuh tahun. Piaget berpendapat bahwa cara berpikir anak-anak berbeda dengan cara berpikir orang dewasa. Berpikir dalam perspektif al-qur'an dan hadits pengertian berpikir (tafkiir. Secara etimologi, tafkir (berpikir) adalah salah satu kerja akal tingkat tinggi. Karena, orang yang berpikir menghadirkan di dalam otaknya gambaran menyeluruh mengenai tema atau masalah yang hendak dibahas dan dianalisis, sebagai tahapan pertama untuk menentukan bingkai umum masalah yang dipikirkan. Inovasi dalam berpikir perspektif Al-Qur'an dan Hadits, Kemampuan manusia untuk berpikir inilah yang menjadikannya sebagai makhluk-Nya yang diberi amanat untuk dapat beribadah kepada-Nya serta diberi tanggung jawab dalam segala pilihan dan keinginannya.
\end{abstract}

Kata kunci: Berpikir, pandangan dasar dalam berpikir, tokoh teori berpikir, berpikir dalam prespektif Al-Qur'an, Inovasi Berpikir

Abstract, Thinking is the process of presenting or manipulating experiences more fully, for example in the process of recalling information, imagining and considering something. Thinking means processing information mentally or cognitively. Some basic insight into thinking Thinking is cognitive, which arises internally in thought but can be predicted from behavior, Thinking is a process involving multiple manipulations of knowledge in cognitive systems, and Thinking is directed and produces problemsolving behaviors. According to Piaget, the logical way of thinking develops gradually, approximately at the age of two and at about seven years. Piaget argues that children's 
way of thinking differs from that of adults. Thinking in the perspective of al-qur'an and hadith the notion of thinking (tafkiir) Etymologically, thinking (thinking) is one of the higher-order work of thought, because the person who thinks presents in his brain the whole picture of the theme or problem to be discussed and analyzed, As the first stage to define the general frame of thought problem.Enhinking innovation in the perspective of the Qur'an and Hadith, the ability of people to think is what makes it a creature who is given the mandate to be able to worship Him and be given responsibility in all Choice and desire.

Keywords: Thinking, basic view in thinking, thinking theory figure, thinking in perspective Al-Qur'an, Innovation Thinking

Pendahuluan

Berpikir adalah memanipulasi data, fakta dan informasi untuk membuat keputusan berperilaku. Jangkauan pikiran dimulai dari lamunan biasa, selanjutnya pemecahan masalah yang kreatif. Aktivitas mental dalam perasaan dan pemahaman bergantung pada peransangan dari luar dalam proses yang disebut sensasi dan atensi. Proses mental yang lebih tinggi yang disebut berpikir terjadi di dalam otak. Mengingat kembali mengundang pengalaman terdahulu ke alam pikiran dan mulai membentuk rantai asosiasi. Rantai asosiasi tidak merujuk pada apa yang secara nyata kita lihat tetapi sebagai khayalan-khayalan mental.

Psikologi pendidikan adalah studi yang sistematis terhadap proses dan faktor-faktor yang berhubungan dengan pendidikan. Sedangkan pendidikan adalah proses pertumbuhan yang berlangsung melalui tindakan-tindakan belajar ${ }^{1}$. Psikologi pendidikan memusatkan perhatian pada persoalan-persoalan yang berkenaan dengan proses dan faktor-faktor yang berhubungan dengan tindakan belajar.

Karena konsentrasinya pada persoalan belajar, yakni persoalan-persoalan yang senantiasa melekat pada subjek didik terutama pada persoalan berpikir, maka konsumen utama psikologi pendidikan ini pada umumnya adalah pada pendidik. Mereka memang dituntut untuk menguasai bidang ilmu ini agar mereka dalam menjalankan fungsinya, dapat menciptakan kondisi-kondisi yang memiliki daya dorong yang besar terhadap berlangsungnya tindakan-tindakan belajar secara efektif dan menyenangkan dengan tentunya melaui proses berpikir yang baik.

\footnotetext{
${ }^{1}$ Jeane Ellis Ormrod, Psikologi Pendidikan Membantu Siswa Tumbuh Dan Berkembang 1ed. (Jakarta: Erlangga, 2009). hlm. 46
} 


\section{A. Teori Berpikir Dalam Psikologi}

\section{Pengertian Berpikir}

Berpikir adalah proses menyajikan atau memanipulasi pengalamanpengalaman secara lebih lengkap, misalnya dalam melakukan proses memanggil kembali informasi, membayangkan dan mempertimbangkan sesuatu ${ }^{2}$.

Berpikir adalah proses memanipulasi yang melibatkan informasi secara mental, seperti membentuk konsep-konsep abstrak, menyelesaikan beragam masalah, mengambil keputusan, dan melakukan refleksi kritis atau menghasilkan gagasan kreatif $^{3}$.

Berpikir adalah berkembangnya ide dan konsep di dalam diri seseorang (Bochenski, 1983). Perkembangan ide dan konsep ini berlangsung melalui proses penjalinan hubungan antara bagian-bagian informasi yang tersimpan di dalam diri seseorang yang berupa pengertian-pengertian. "Berpikir" mencakup banyak aktivitas mental. Contoh kita berpikir saat melamun sambil menunggu kuliah pengantar psikologi dimulai. Kita berpikir saat mencoba memecahkan ujian yang diberikan di kelas. Kita berpikir saat menulis artikel dan berbagai aktifitas yang dilakukan tak terlepas dari proses berpikir.

Berpikir adalah suatu kegiatan mental yang melibatkan kerja otak. Walaupun tidak bisa dipisahkan dari aktivitas kerja otak, pikiran manusia lebih dari sekedar kerja organ tubuh yang disebut otak. Kegiatan berpikir juga melibatkan seluruh pribadi manusia dan juga melibatkan perasaan dan kehendak manusia. Memikirkan sesuatu berarti mengarahkan diri pada obyek tertentu, menyadari secara aktif dan menghadirkannya dalam pikiran kemudian mempunyai wawasan tentang obyek tersebut.

Berpikir berarti memproses informasi secara mental atau secara kognitif. Secara lebih formal, berpikir adalah penyusunan ulang atau manipulasi kognitif baik informasi dari lingkungan maupun simbol-simbol yang disimpan dalam long term memory.

\section{Pandangan Dasar Berpikir}

Berpikir dimulai ketika muncul keraguan dan pertanyaan untuk menemukan jawaban dari suatu permasalahan atau masalah yang memerlukan pemecahan. Charles S. Pierce mengemukakan bahwa bahwa dalam berpikir ada dinamika gerak

\footnotetext{
${ }^{2}$ Kartono K. and Gulo D., Kamus Psikologi (Bandung: Pionir Jaya, 2003). hlm. 86

${ }^{3}$ Singgih D. Gunarsa, Psikologi Perkembangan Anak Dan Remaja (Jakarta: Gunung Mulia, 2008). hlm. 78
} 
dari adanya gangguan suatu keraguan (irritation of doubt) atas kepercayaan atau keyakinan yang selama ini dipegang, lalu terangsang untuk melakukan penyelidikan (inquiry) kemudian diakhiri dengan pencapaian suatu keyakinan baru. Terdapat beberapa pandangan dasar dalam berpikir, yaitu :

a. Berpikir adalah kognitif, yaitu timbul secara internal dalam pikiran tetapi dapat diperkirakan dari perilaku,

b. Berpikir merupakan sebuah proses yang melibatkan beberapa manipulasi pengetahuan dalam sistem kognitif, dan

c. Berpikir diarahkan dan menghasilkan perilaku yang memecahkan masalah atau diarahkan pada solusi.

Plato beranggapan bahwa berpikir adalah berbicara dalam hati. Sehubungan dengan pendapat Plato ini, ada yang berpendapat bahwa berpikir adalah aktivitas ideasional (Woodworth dan Marquis, dalam Suryabrata, 1995:54). Pada pendapat ini dikemukakan dua kenyataan, yakni :

a. Berpikir adalah aktivitas; jadi subyek yang berpikir aktif.

b. Aktivitas bersifat ideasional; jadi bukan sensoris dan bukan motoris, walaupun dapat disertai oleh kedua hal itu; berpikir menggunakan abstraksi-abstraksi atau "ideas".

\section{Teori Berpikir Menurut Piaget}

Menurut Piaget, cara berpikir logis berkembang secara bertahap, kira-kira pada usia dua tahun dan pada sekitar tujuh tahun. Piaget berpendapat bahwa cara berpikir anak-anak berbeda dengan cara berpikir orang dewasa. Perbedaan anak-anak yang lebih kecil dan anak-anak yang lebih besar tidak selalu berkaitan dengan persoalan bahwa anak yang lebih besar mempunyai pengetahuan lebih banyak. Melainkan karena pengetahuan mereka berbeda jenis, dengan penemuan ini Piaget mulai mengkaji perkembangan struktur mental. Adapun tahapan-tahapan perkembangan menurut Piaget :

a. Tahap Sensori Motor

Berlangsung dari kelahiran 0 hingga usia 2 tahun. Pada tahap ini, bayi membangun suatu pemahaman tentang dunia dengan mengkoordinasikan pengalam-pengalaman sensor (seperti melihat dan mendengar) dengan tindakan motorik fisik, yang disebut sensorimotor.

b. Tahap Praoperasional 
Berlangsung kira-kira dari usia 2 hingga 7 tahun. Pada tahap ini, anak-anak mulai meluksikan dunia dengan kata-kata dan gambar. Menurut Piaget, anakanak belum mampu melaksanakan apa yang disebut operasi-tindakan mental dengan cara diinternalisasikan dalam bentuk melakukan secara mental apa yang sebelumnya dilakukan secara fisik.

c. Tahap Operasional Konkret

Berlangsung kira-kira dari usia 7-11 tahun. Pada tahap ini anak-anak dapat melaksanakan operasi, dan penalaran logis menggantikan pemikiran intuitif sejauh pemikiran dapat diterapkan ke dalam contoh-contoh yang spesifik atau konkret.

d. Tahap Operasional Formal

Berlangsung kira-kira dari usia 11-15 tahun. Pada tahap ini individu melampaui dunia nyata, pengalaman-pengalaman konkret dan berpikir secara abstrak dan lebih logis. Sebagai bagian dari pemikiran yang lebih abstrak, anakanak remaja mengembangkan gambaran keadaan yang ideal. Mereka dapat berpikir seperti apakah orang tua yang ideal dan membandingkan orang tua mereka dengan standard ideal ini. Mereka mulai mempersiapkan kemungkinan-kemungkinan bagi masa depan dan terkagum-kagum terhadap apa yang dapat mereka lakukan.

\section{B. Berpikir Dalam Perspektif Al-Qur'an dan Hadits}

\section{Pengertian Berpikir (Tafkiir) Secara Etimologi}

Secara etimologi, berpikir berasal dari beberapa istilah berikut, diantaranya yaitu :

a. Fakkara fil-amri fakran, artinya : mempergunakan akalnya dalam urusan dan menyusun sebagian info yang diketahui untuk mendapatkan info yang tidak diketahui ${ }^{4}$.

b. Fakkara fil-amri, adalah bentuk mubalaghah dari fakara, dan lebih sering dipakai daripada fakara. Fakkara fil-musykilah artinya : mempergunakan akalnya untuk mencari solusi masalah. Fa'il-nya : mufakir. Fakkara fulaanan bil-amri artinya : menyinggung dan mengingatkan masalah itu kepada orang lain.

c. Iftakara artinya : mengingat. Iftakara fil-amri : artinya mempergunakan akalnya dalam persoalan yang dihadapi.

\footnotetext{
${ }^{4}$ M. Sayyid Muhammad Az-Za'Balawi, Pendidikan Remaja Antara Islam Dan Ilmu Jiwa (Jakarta: Gema Insani, 2007). Hlm. 60
} 
d. At-tafkir artinya : menggunakan akal dalam menghadapi suatu masalah guna mendapatkan solusinya.

e. Al-fikr artinya : menggunakan akal dalam ilmu untuk mendapatkan pengetahuan yang masih belum diketahui.

f. Lii fil-amri fikrun artinya : dalam masalah ini saya punya ide dan gagasan.

g. Al-fikrah artinya : gambaran dalam pikiran tentang sesuatu hal.

h. Al-fikr artinya : mempergunakan pikiran dalam sesuatu persoalan. Jamaknya afkaar / fikkir artinya : orang yang banyak berpikir.

Dengan demikian, tafkir (berpikir) adalah salah satu kerja akal tingkat tinggi. Karena, orang yang berpikir menghadirkan di dalam otaknya gambaran menyeluruh mengenai tema atau masalah yang hendak dibahas dan dianalisis, sebagai tahapan pertama untuk menentukan bingkai umum masalah yang dipikirkan.

Imam Abu Hamid al-Ghazali, dalam Ihyaa' 'Ulumuddiin mendefinisikan tafkiir dengan menghadirkan dua pengetahuan di dalam hati untuk menghasilkan pengetahuan ketiga 5 .

\section{Pengertian Berpikir (Tafkiir) dalam Al-Qur'an}

Kata fakkara (yang bertasydid) telah berulang kali disebutkan dalam al-Qur'an dalam bentuk fi 'il madhi dan mudhari' kira-kira dalam Sembilan belas ayat. Bentuk fakkara disebutka satu kali, yaitu dalam firman-Nya dalam QS. Al-Muddatsir : 18.

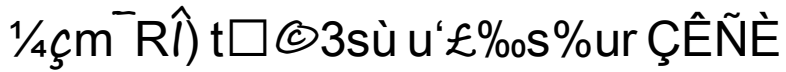

Artinya : Sesungguhnya Dia telah memikirkan dan menetapkan (apa yang ditetapkannya). (Q.S. Al-Muddatsir : 18).

Ayat ini turun berkenaan dengan Al-Walid Ibnul-Mughirrah. Tatkala mendengar mendengar ayat-ayat Al-Qur'an yang dibaca oleh Rasulullah, seolah-olah hatinya tersentuh. Hal itu di dengar oleh Abu Jahal, yang kemudian berkata kepadanya, "Paman, kaummu ingin mengumpulkan harta untuk diberikan kepadamu. Engkau telah menemui Muhammad, tapi ternyata engkau justru terpengaruh olehnya".

Al-Walid menjawab "Orang Quraisy sudah tahu bahwa aku adalah orang yang paling kaya. Aku tidak mau menerima harta itu"

Kata Abu Jahal "Kalau begitu, katakanlah sesuatu kaummu tahu bahwa bahwa engkau benci dan tidak setuju dengan ajaran Muhammad".

\footnotetext{
${ }^{5}$ M. Sayyid Muhammad Az-Za'Balawi, Pendidikan Remaja Antara Islam Dan Ilmu Jiwa (Jakarta: Gema Insani, 2007) hlm. 65
} 
Al-Walid menjawab “Apa yang bisa ku katakana? Demi Allah, tidak ada seseorang yang lebih tahu tentang seluk beluk syair, bahkan tentang syair-syair jin sekalipun, ketimbang aku. Demi Allah, yang dibaca Muhammad sama sekali tidak mirip dengan syair. Demi Allah, ucapannya sangat indah dan merdu. Atasnya berbuah lebat, dan bawahnya berakar kokoh. Dia tinggi dan tidak ada yang mampu melebihi ketinggiannya".

Abu Jahal berkata, "Kaummu tidak terima, kecuali jika engkau mengatakan sesuatu tentang ajaran Muhammad".

Akhirnya Al-Walid berkata, "Baiklah. Biarkan aku berpikir dulu". Setelah ia berpikir, dia berkata "Ajaran Muhammad itu tidak lain hanyalah sihir". Mendengar hal itu, orang-orang kafir Quraisy menjadi kagum.

Ini adalah pikiran yang salah, sesat dan menyesatkan. Dia mempergunakan akal secara terbalik. Sebab, masalah yang dipersilihkan (yaitu bahwa Al-Qur'an adalah firman Allah) telah sangat jelas baginya, dan dengan begitu seharusnya dia bersaksi (bersama kaum mukminin) bahwa tiada Tuhan selain Allah dan bahwa Muhammad adalah hamba dan Rasul-Nya. Itulah sebab langsung yang mendorongnya untuk berpikir secara terbalik, membuatnya mengatakan tentang kebenaran yang nyata bahwa "dia tidak lain hanyalah sihir belaka".

Pengakuan Al-Qur'an akan adanya jenis pemikiran yang salah dan penggunaan akal secara terbalik ketika memikirkan hal-hal yang sudah jelas dan didukung bukti-bukti yang kuat, menegaskan bahwa tema-tema pemikiran terpengaruh oleh kecenderungan pribadi setiap individu' ${ }^{6}$ Pengakuan Al-Qur'an ini juga menjadi peringatan agar tidak mengikuti kecenderungan yang menyimpang ini dalam masalah apa pun. Makanya Allah memperingatkan. Salah satunya dalam firman Allah SWT dalam Q.S. Al-Baqarah ayat 266 :

-Šuqtfr\& öNà2 $\beta \%$ otnr\& br\& šcqä3s? 1/4çms9 ×p“Yy_ “ï̈B $9 @$ Šï, R

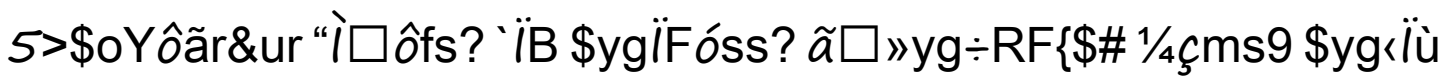

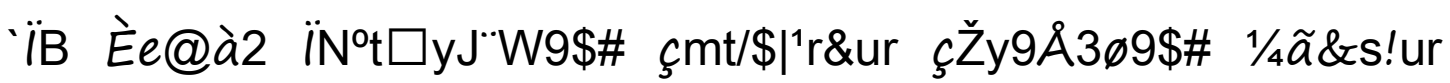
xp-fíh'èCE âä!\$xÿyèàÊ !\$ygt/\$|'r'sù Ö‘\$|Áôâ̂il) Ïm<ïù Ö'\$tR ôMs\%uŽtlôm\$\$sù 3 š• ̈̈90xıx. Úúîiüt7âf a!\$\# ãNà6s9 ïM»tfFy\$\#

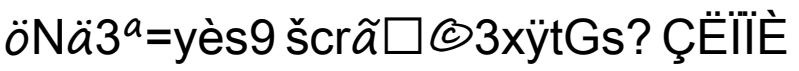

\footnotetext{
${ }^{6}$ Sayyid Muhammad, Pendidikan remaja ... Hlm. 62
} 
Artinya : Apakah ada salah seorang di antaramu yang ingin mempunyai kebun kurma dan anggur yang mengalir di bawahnya sungai-sungai; Dia mempunyai dalam kebun itu segala macam buah-buahan, kemudian datanglah masa tua pada orang itu sedang Dia mempunyai keturunan yang masih kecil-kecil. Maka kebun itu ditiup angin keras yang mengandung api, lalu terbakarlah. Demikianlah Allah menerangkan ayat-ayat-Nya kepada kamu supaya kamu memikirkannya[169].

Ayat ini mengandung dua idraak (penglihatan). Yang pertama adalah idraak kondisi kini, sedang yang kedua adalah idraak (masa depan). Keduanya merupakan dua buah premis yang menghasilkan kesimpulan. Kesimpulan inilah yang menjadi objek berpikir yang dinyatakan dalam bagian akhir ayat.

Objek idraak yang pertama sifatnya idrawi, yaitu melihat kebun dalam keadaannya sekarang, yang teduh, pohon-pohonnya berbuah lebat, buahnya beraneka macam dan rasa.

Objek idraak yang kedua sifatnya juga inderawi, yaitu melihat kebun ini, yang keadaannya telah berubah karena diterpa angina keras yang megandung api yang membakar segala bentuk kehidupan dan kesenangan di dalamnya. Penghadiran dua keadaan itulah yang menjadi objek berpikir.

Bentuk yatafakkaruu ini disebutkan dua kali. Salah satunya dalam firman Allah SWT dalam Q.S. Ar-Ruum : 8

\section{öNs9urr\& (\#rã $\square$ (c)3xÿtGtf p'î̂ NíkÄ!äÿRr\& 3 \$“B t,n=y\{ a!\$\#

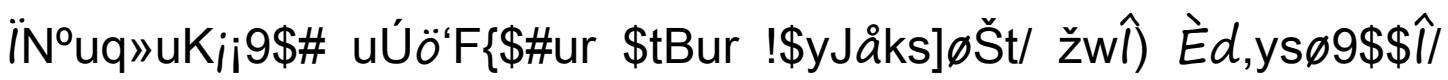

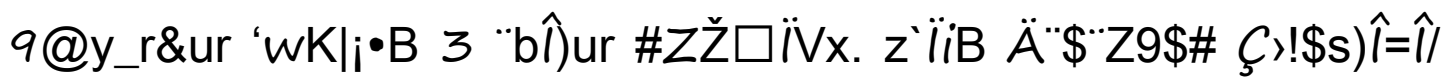 öNî̀in/u'tbrã $\square \ddot{l y ̈ » s 3 s 9 ~ C ̧ N ̃ E ~}$}

Artinya : dan mengapa mereka tidak memikirkan tentang (kejadian) diri mereka? Allah tidak menjadikan langit dan bumi dan apa yang ada diantara keduanya melainkan dengan (tujuan) yang benar dan waktu yang ditentukan. dan Sesungguhnya kebanyakan di antara manusia benar-benar ingkar akan Pertemuan dengan Tuhannya. (Q.S. Ar-Ruum : 8)

Ayat di atas mengajak seluruh umat manusia untuk memikirkan kejadian diri mereka sendiri dan juga makhluk serta benda-benda yang diciptakan Allah SWT di alam ini. Ayat ini mendorong untuk membuang kelengahan dan kebodohan yang mendekatkan manusia ke tingkah binatang, padahal manusia adalah makhluk yang istimewa di antara seluruh makhluk yang hidup di jagad raya. Jadi kalau manusia 
menggunakan akal mereka, memikirkan tabiat diri mereka, terbukalah sebagian rahasia penciptaan manusia yang menjadi saksi keesaan Allah, kekuasaan-Nya dan hikmah-Nya.

\section{Tingkat-tingkat Berpikir}

Berpikir merupakan operasi yang dilakukan oleh akal. Permulaan proses ini terjadi pada masa balita dan terus mengalami pertumbuhan. Pada masa kanak-kanak, berpikir tidak terfokus pada metode induktif, yaitu pindah dari bagian kecil ke total keseluruhan. Dia meneliti fakta-fakta dan menelaah konsep-konsep parsial dari objek, berusaha menyingkap dan mengetahui berbagai hal secara bertahap dari bagian kecil ke total keseluruhan.

Dalam kondisi pertama, dia perlu mengambil langkah-langkah serius dalam pemikirannya untuk mendapatkan solusi yang benar, yang tidak bertentangan dengan hukum-hukum dan prinsip-prinsip lingkungan sosialnya. Dalam kondisi kedua, manusia memperhatikan jenis rintangan, kadang sebabnya diri individu itu sendiri, tabiat, tujuan atau lingkungan sosial. Berikut ini tahapan-tahapan berpikir :

a. Merasa ada masalah

Proses berpikir dimulai ketika remaja menghadapi masalah atau problem yang mempengaruhi kehidupannya. Manusia berpikir untuk mendapati dirinya kecenderungan kuat untuk mendapatkan solusi yang memuaskan, yang meredakan ketegangannya. Mulailah melakukan berbagai aktivitas berpikir untuk mengatasi masalah-masalah dan masalah-masalah yang ditemui.

b. Menentukan objek berpikir

Penentuan objek berpikir akan menghemat tenaga dan waktu, menghasilkan kesimpulan yang benar, dan proses serta metodologi berpikir itu sendiri benar. Penelitian terkadang bercabang atau panjang, kadang remaja tidak bisa memilahmilahnya. Nabi Ibrahim menentukan tema berpikir dalam perdebatannya dengan raja Namrd. Ia membatasi tema berpikir dalam masalah rububiyah (ketuhanan). Ia juga menentukan tema berpikir dalam dialognya dengan kaumnya. Allah berfirman dalam QS. Al-baqarah : 258

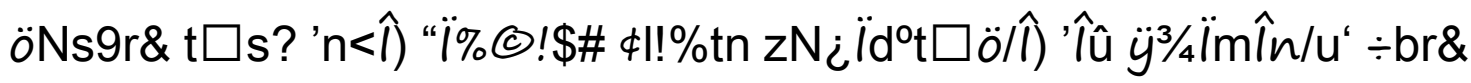
çm9s?\#uä a! \$\# š・ "ï\%@!\$\# 3/4ÇCósâf àMiïJaffur tA\$s\% O\$tRr\& 3/4ÄÓóré\& àM<ïBé\&ur (
} 


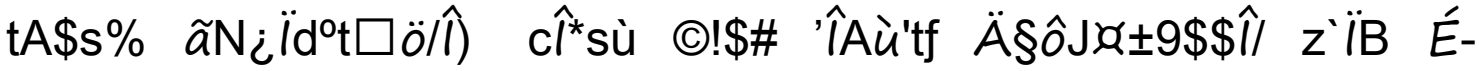

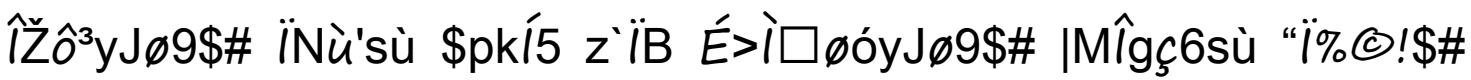

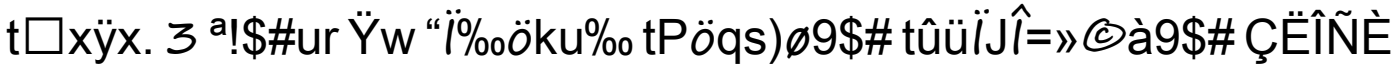

Artinya : Apakah kamu tidak memperhatikan orang yang mendebat Ibrahim tentang Tuhannya (Allah) karena Allah telah memberikan kepada orang itu pemerintahan (kekuasaan). ketika Ibrahim mengatakan: "Tuhanku ialah yang menghidupkan dan mematikan," orang itu berkata: "Saya dapat menghidupkan dan mematikan".Ibrahim berkata: "Sesungguhnya Allah menerbitkan matahari dari timur, Maka terbitkanlah Dia dari barat," lalu terdiamlah orang kafir itu; dan Allah tidak memberi petunjuk kepada orang-orang yang zalim.

Raja Namrud tidaklah mengingkari wujud Allah, melainkan mengingkari keesaan-Nya dalam sifat uluhiah dan rububiyah, serta mengingkari bahwa dia yang mengatur alam semesta ini.

c. Mengumpulkan hipotesis

Setelah menentukan tema berpikir dan menjelaskan ruang lingkupnya, seorang pemikir melangkah ke tahapan selanjutnya yaitu membahas tema secara riil. Maka mulailah mengumpulkan data-data lama (yang sudah diketahuinya) yang berkaitan dengan masalah yang dipikirkan ${ }^{7}$.

Dialog nabi Ibrahim dengan kaumnya menegaskan urgensi akal dalam menjukkan pokok-pokok agama dan menciptakan keyakinan akan seluruh persoalan akidah, dengan sarana berpikir dan meneliti secara berulang-ulang mengenai jiwa, kehidupan, makhluk hidup dan seluruh alam semesta. Maka tidak lama setelah itu, dia akan berkata bersana kaum mukminin, sesuai firman Allah SWT dalam Q.S. Al-Imran : 191

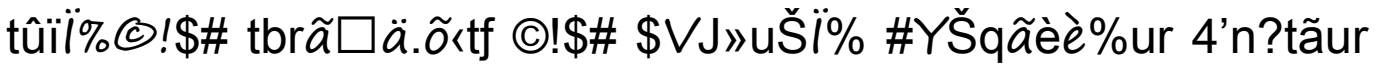

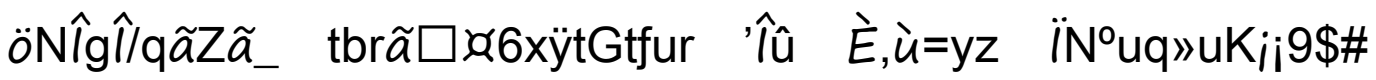
ÇÚö‘F\{\$\#ur \$uZ-/u’ \$tB |Mø)n=yz \#xı»yd Wxï̈»t/

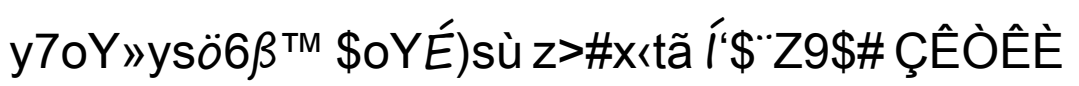

Artinya : (yaitu) orang-orang yang mengingat Allah sambil berdiri atau duduk atau dalam keadan berbaring dan mereka memikirkan tentang penciptaan

\footnotetext{
${ }^{7}$ M. Sayyid Muhammad Az-Za'Balawi, Pendidikan Remaja Antara Islam Dan Ilmu Jiwa (Jakarta: Gema Insani, 2007) hlm. 68
} 
langit dan bumi (seraya berkata): "Ya Tuhan Kami, Tiadalah Engkau menciptakan ini dengan sia-sia, Maha suci Engkau, Maka peliharalah Kami dari siksa neraka.

d. Memilah-milah hipotesis

Pemilihan hipotesis dianggap sebagai fase berpikir yang sangat penting dan menentukan. Oleh karena itu, remaja yang sedang melakukan proses berpikir yang meneliti dan mencari kebenaran, yang baru terjun kedalam arena ini, harus melepaskan intuisinya, kecenderungan dan motivasinya. Hal ini bertujuan agar semua itu tidak berpengaruh secara langsung terhadap akal ketika sedang melakukan operasi berpikir, agar kesimpulan yang hendak dicapai tidak terpengaruh.

Al-Qur'an telah menjelaskan sejumlah metode berpikir yang benar, yang mengantarkan kepada kebenaran mutlak. Nabi Ibrahim, tatkala berdialog dengan kaumnya untuk membuktikan kekeliruan kepercayaan mereka dan penyembahan berhala yang mereka lakukan. Dengan cara menyisihkan emosi keagamaan dan prinsip kepercayaan, sehingga terlihat seolah-olah semua itu tidak punya pengaruh terhadap operasi berpikir saat berdialog. Bahkan, Nabi Ibrahim mengalahkan emosi keagamaan dan keyakinannya untuk menarik lawan dialog, agar lawan tersebut tidak menjauh darinya.

Islam sangat menganjurkan untuk berpikir logis dan independen sebagai jalan untuk mendapatkan keyakinan tentang pokok-pokok agama, hukum-hukum syariat, ibadah, serta prinsip-prinsip pendidikan dan akhlak dalam agama. Kematangan akal dan kemampuannya untuk berpikir secara mandiri, memahami, mengingat dan berkhayal, dianggap sebagai ciri khas fase remaja. Allah menganugerahi manusia berbagai bakat untuk dipergunakan dalam memperkuat iman dan keyakinannya, serta untuk meningkatkan diri di bidang ilmu pengetahuan dan menunaikan tugas-tugas sebagai khalifah di muka bumi.

\section{Proses berpikir}

a. Tahap pertama menghadirkan di dalam otaknya gambaran menyeluruh mengenai tema atau masalah yang hendak dibahas dan dianalisis untuk menentukan bingkai umum masalah yang dipikirkan.

b. Tahap kedua, kembali memikirkan bingkai yang lengkap, sebagai langkah awal untuk menentukan bagian-bagian parsialnya. 
c. Tahap ketiga, memulai mengumpulkan data-data yang berkaitan dengan topik, dengan memulai dari fenomena-fenomena indrawi dan data-data lama yang berkaitan langsung dengan tema atau data-data yang dekat dan mirip dengannya.

d. Tahap keempat, memikirkan semuanya secara lebih mendalam untuk mencapai sebuah atau beberapa pengetahuan baru yang didapat oleh akal untuk membedakan topik masalah dan menampilkannya dalam bentuk yang jelas dan final. Al-Qur'an memakai tingkat berpikir ini ketika membuktikan sifat uluhiah (ketuhanan) dan keesaan Allah.

\section{Berpikir (Inovasi dalam Psikologi Pendidikan Islam)}

\section{Inovasi dalam berpikir (perspektif Al-Qur'an dan Hadits)}

Inovasi adalah cara baru melakukan sesuatu hal yang menghasilkan perubahan positif dan membuat hidup kita menjadi lebih baik ${ }^{8}$. Inspirasi yang kuat dan visi yang besar, sangat diperlukan dalam membentuk sebuah inovasi. Inti inovasi adalah menciptakan ide-ide yang baru dan kreatif untuk memecahkan masalah.

Keistimewaan manusia yang membedakannya dari binatang adalah akal yang dianugerahkan Allah padanya. Sehingga, manusia mampu berpikir dan memungkinkan pula baginya untuk mengamati, menganalisis banyak hal dan kejadian, kemudian menyimpulkan keseluruhan permasalahan dari potonganpotongannya dan juga mengambil hasil dari primer-primer yang ada. Kemampuan manusia untuk berpikir inilah yang menjadikannya sebagai makhluk-Nya yang diberi amanat untuk dapat beribadah kepada-Nya serta diberi tanggung jawab dalam segala pilihan dan keinginannya ${ }^{9}$. Akal pula yang menjadikan manusia terpilih untuk menjadi khalifah di muka bumi ini dan berkewajiban untuk membangunnya dengan sebaik-baiknya.

Semua informasi dan ilmu yang didapatkan manusia sejak kecilnya, dijadikan landasan dasar dalam proses berpikirnya di kemudian hari. Islam menaruh perhatian besar akan perkembangan proses berpikir manusia dengan menyerukannya untuk mengamati semua yang ada di langit dan di bumi, mengamati dii sendiri dan semua mahluk-Nya. Sebagaimana Allah berfirman dalam Q.S. Fushilat : 53

\footnotetext{
${ }^{8}$ M. Yunus S.B., Mindset Revolution : Optimalisasi Potensi Otak Tanpa Batas (Yogyakarta: Galangpress, 2014). Hlm. 97

${ }^{9}$ Musfir bin Said Az-Zahra, Konseling Terapi (Jakarta: Gema Insani, 2005). Hlm. 274
} 


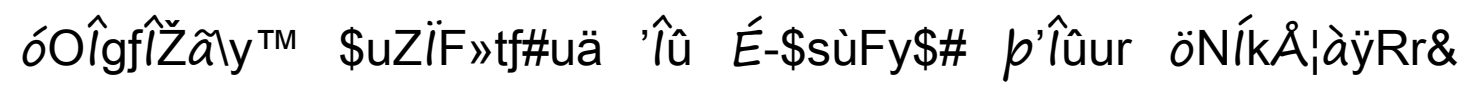
4Ó@Lym tû üt7oKtf öNßgss9 çm ${ }^{-} \operatorname{Rr} \&$ ',ptø:\$\# 3 öNs9urr\& É\#ô3tf

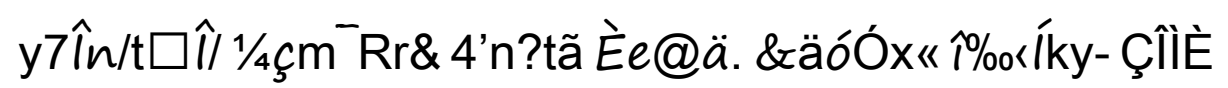

Artinya : Kami akan memperlihatkan kepada mereka tanda-tanda (kekuasaan) Kami di segala wilayah bumi dan pada diri mereka sendiri, hingga jelas bagi mereka bahwa Al Quran itu adalah benar. Tiadakah cukup bahwa Sesungguhnya Tuhanmu menjadi saksi atas segala sesuatu? (Q.S. Fushilat : 53)

Allah selalu memerintahkan manusia untuk berpikir akan diri mereka sendiri, sebagai mana firman-Nya

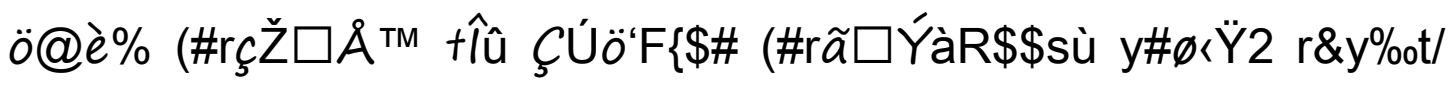

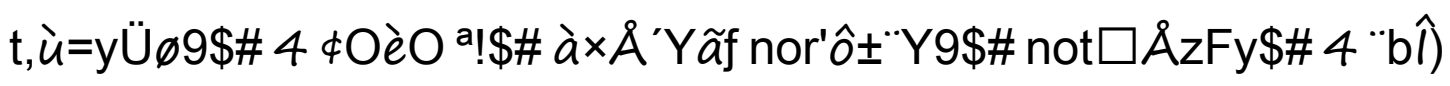

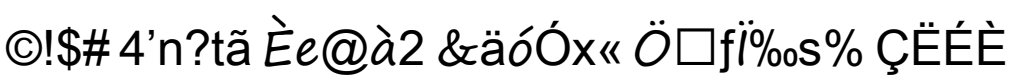

Artinya : Katakanlah: "Berjalanlah di (muka) bumi, Maka perhatikanlah bagaimana Allah menciptakan (manusia) dari permulaannya, kemudian Allah menjadikannya sekali lagi. Sesungguhnya Allah Maha Kuasa atas segala sesuatu. (Q.S. Al-Ankabut : 20)

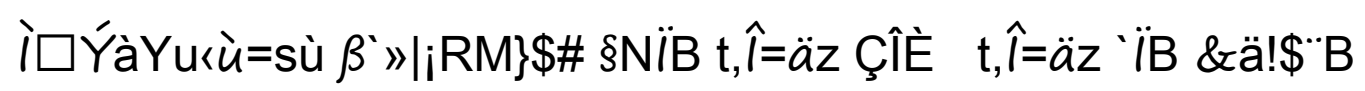

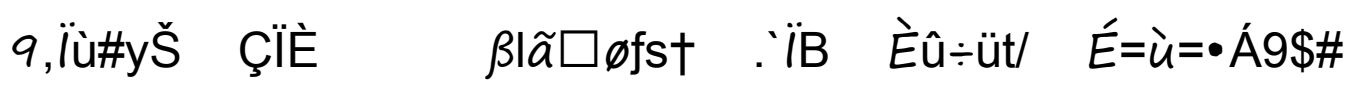

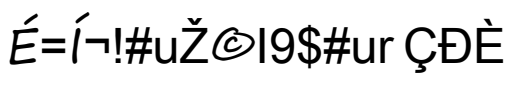

Artinya : 5. Maka hendaklah manusia memperhatikan dari Apakah Dia diciptakan? 6. Dia diciptakan dari air yang dipancarkan, 7. yang keluar dari antara tulang sulbi laki-laki dan tulang dada perempuan. (Q.S. Ath-Thariq : 5-7)

Allah memerintahkan manusia untuk memperhatikan alam semesta dan juga mengamati fenomena alam yang beraneka ragam dengan merenungkan penciptaan dan proses keteraturan yang ada di dalamnya. Semua ini akhirnya akan menjadi informasi dan ilmu pengetahuan yang bermanfaat bagi manusia. Dengan demikian, manusia dapat mengetahui sunnah dan peraturan yang telah Allah tetapkan di segala bidang konsentrasi ilmu pengetahuan yang beraneka ragam.

Allah menjelaskan mengenai orang-orang yang tidak mempergunakan akal dan pikirannya. Sesungguhnya mereka berada di derajat terendah melebihi rendahnya derajat binatang, sebagaimana firman-Nya dalam Al-Quran, Surah Al-Anfaal : 22 


\section{**bî) §žY̌ Éb Ÿw tbqè=É) $\div$ ètf ÇËËE}

Artinya : Sesungguhnya binatang (makhluk) yang seburuk-buruknya pada sisi Allah ialah; orang-orang yang pekak dan tuli yang tidak mengerti apa-apapun. (Q.S. Al-Anfaal : 22)

Dalam ayat di atas, dijelaskan bahwa manusia yang paling buruk di sisi Allah ialah yang tidak mau mendengar, menuturkan dan memahami kebenaran ${ }^{10}$.

Rasulullah menyeru manusia untuk memikirkan ayat-ayat Al-Qur'an dan juga merenungkan semua penciptaan-Nya, sebagaimana diriwayatkan dari Abu Hurairah bahwa Rasulullah bersabda :

"Berpikir selama sejam lamanya lebih baik daripada beribadah selama setahun” (HR. Ibnu Habban)

Selain itu, Rasulullah memuji orang-orang yang mempergunakan akalnya untuk berpikir, sebagaimana diriwayatkan dari Ubaidillah bin Muadz dari bapaknya, bahwa Rasulullah bersabda kepada Asyaj Abdul Qais

"Sesungguhnya kamu memiliki dua hal yang membuatmu dicintai Allah dan Rasul-Nya, lemah lembut dan tidak ceroboh" (HR. Muslim)

Dalam keterangannya tentang Hadits ini, Imam Nawawi mengungkapkan bahwa yang dimaksud dengan lemah lembut di sini adalah akal, dan yang dimaksu dengan tidak ceroboh disini adalah ketepatan dalam segala sesuatunya hingga ia tidak terburu-buru dalam penyelesaiannya. Akal inilah yang membuat manusia memiliki sifat-sifat terpuji, yang dengannya ia dicintai Allah dan Rasul-Nya. Sesungguhnya akal mampu menjadi petunjuk bagi manusia dalam membedakan sesuatu yang baik dan benar ataupun sesuatu yang buruk dan menyesatkan.

\section{Inovasi dalam proses berpikir untuk memecahkan masalah}

Manusia banyak menghadapi permasalahan dalam hidupnya, yang semuanya ini membutuhkan solusi dan pemecahannya. Di saat manusia mencari solusi ataupun pemecahan atas permasalahan yang sedang dihadapinya, maka hendakanya ia mengikuti tahapan sebagai berikut :

a. Meyakini adanya permasalahan yang sedang dihadapi. Apakah permasalahan ini mempunyai kepentingan dalam hidupnya?

${ }^{10}$ Musfir bin Said Az-Zahra, Konseling Terapi (Jakarta: Gema Insani, 2005) hlm 277 
b. Mengumpulkan banyak informasi sekitar permasalahan yang sedang dihadapi hingga permasalahan tersebut tampak jelas adanya serta dapat ditentukan nilai dan batasannya secara mendetail hingga mempermudah dalam pencarian solusinya.

c. Meletakkan opsi-opsi yang sekiranya bisa menjadi solusi atau pemecahan permasalahan.

d. Rekontruksi opsi pemecahan permasalahan. Di saat seseorang berpikir untuk merumuskan suatu pemecahan permasalahan, maka hendaknya ia menganalisis terlebih dahulu opsi-opsi ini dan membahasnya sesuai dengan informasi yang didapatkannya disertai dengan bukti-bukti yang dapat menunjang terlaksananya opsi ini hingga menjadi kokoh dan dapat diaplikasikan.

e. Pemeriksaan lebih lanjut dengan mengindahkan opsi-opsi yang dianggap tidak layak hingga dapat dipilih opsi terbaik dalam memecahkan permasalahan yang ada. Selanjutnya dikumpulkan banyak informasi yang lebih banyak dan lebih membantu dalam merekontruksi kembali opsi ini agar lebih aplikatif dalam berbagai kondisi.

\section{Daftar Pustaka}

Az-Za'Balawi, M. Sayyid Muhammad. Pendidikan Remaja Antara Islam Dan Ilmu Jiwa. Jakarta: Gema Insani, 2007.

Az-Zahra, Musfir bin Said. Konseling Terapi. Jakarta: Gema Insani, 2005.

Gunarsa, Singgih D. Psikologi Perkembangan Anak Dan Remaja. Jakarta: Gunung Mulia, 2008.

K., Kartono and Gulo D. Kamus Psikologi. Bandung: Pionir Jaya, 2003.

Ormrod, Jeane Ellis. Psikologi Pendidikan Membantu Siswa Tumbuh Dan Berkembang 1ed. Jakarta: Erlangga, 2009.

S.B., M. Yunus. Mindset Revolution : Optimalisasi Potensi Otak Tanpa Batas. Yogyakarta: Galangpress, 2014.

Walgito, Bimo. 2008. Pengantar Psikologi Umum. Yogyakarta : PT andi publisher 
Wahandi. 2010. Perkembangan Berbicara (Bahasa) Pada Anak-Anak Usia Dini.

Santrock, John W..2007. Perkembangan Anak. Erlangga

Maulina, Dita. Perkembangan Bahasa Anak. 